\title{
Interactive Effects of Copper Sources and a High Level of Phytase in Phosphorus-Deficient Diets on Growth Performance, Nutrient Digestibility, Tissue Mineral Concentrations, and Plasma Parameters in Nursery Pigs
}

\author{
Ping Ren ${ }^{1}$ (1) - Juxing Chen ${ }^{1} \cdot$ Deana Hancock ${ }^{1} \cdot$ Mercedes Vazquez-Añón ${ }^{1}$
}

Received: 1 December 2020 / Accepted: 5 January 2021 / Published online: 11 January 2021

(C) The Author(s) 2021

\begin{abstract}
The present study investigated the interactive effects of copper sources and a high level of phytase on growth performance, nutrient digestibility, tissue mineral concentrations, and plasma parameters in nursery pigs. Weaning piglets $(N=192 ; 6.06 \pm$ $0.99 \mathrm{~kg}$ ), blocked by body weight, were randomly allotted to 1 of 4 dietary treatments, with 12 pens per treatment and 4 pigs per pen. A basal diet for each phase was formulated to meet nutrient requirements for nursery pigs with the exception that standardized total tract digestibility (STTD) $\mathrm{P}$ was reduced by $0.12 \%$ and $\mathrm{Ca}$ was adjusted to achieve $\mathrm{Ca} / \mathrm{STTD} P=2.15$. The 4 dietary treatments were arranged in a $2 \times 2$ factorial design, with $2 \mathrm{Cu}$ sources $(125 \mathrm{mg} / \mathrm{kg} \mathrm{Cu}$ from copper methionine hydroxy analogue chelate (Cu-MHAC) or copper sulfate $\left.\left(\mathrm{CuSO}_{4}\right)\right)$ and 2 phytase levels $(0$ or 1500 phytase units $(\mathrm{FTU}) / \mathrm{kg})$. Results showed that there was an interaction $(P<0.05)$ between $\mathrm{Cu}$ sources and phytase on ADG during days $0-41$. When phytase was not present in the diets ( $\mathrm{P}$ deficient), there was no difference between the two $\mathrm{Cu}$ sources in terms of ADG during days $0-41$, whereas with phytase in the diets, $\mathrm{Cu}-\mathrm{MHAC}$ tended to improve $(P<0.10)$ ADG during days $0-41$ compared with $\mathrm{CuSO}_{4}$. Pigs fed $\mathrm{Cu}-$ MHAC had greater apparent total tract digestibility (ATTD) of neutral and acid detergent fiber and STTD of P than those fed $\mathrm{CuSO}_{4}$. Phytase increased $(P<0.05)$ growth performance, ATTD of $\mathrm{Ca}$ and $\mathrm{P}$, and plasma inositol and growth hormone concentrations. In conclusion, $\mathrm{Cu}-\mathrm{MHAC}$ may be more effective in improving growth rate than $\mathrm{CuSO}_{4}$ when phytase was supplemented at $1500 \mathrm{FTU} / \mathrm{kg}$. Cu-MHAC enhanced fiber and P digestibility regardless of phytase, compared with $\mathrm{CuSO}_{4}$. Phytase addition in P-deficient diets was effective in improving growth performance, $\mathrm{Ca}$ and $\mathrm{P}$ digestibility, and plasma inositol and growth hormone concentrations.
\end{abstract}

Keywords Copper $\cdot$ Fiber digestibility $\cdot$ Growth performance $\cdot$ Phosphorus digestibility $\cdot$ Pigs $\cdot$ Phytase

\section{Introduction}

High levels of copper sulfate $\left(\mathrm{CuSO}_{4}, 150\right.$ to $\left.250 \mathrm{mg} / \mathrm{kg} \mathrm{Cu}\right)$ are widely used in nursery pigs to promote growth and improve feed efficiency [1]. It has been demonstrated that chelated $\mathrm{Cu}$ is more bioavailable in both chickens and pigs than $\mathrm{CuSO}_{4}[2,3]$. Supplementation of $\mathrm{Cu}$ as Cu-citrate $(125 \mathrm{mg} / \mathrm{kg}$ $\mathrm{Cu})$ or $\mathrm{Cu}$-proteinate $(100 \mathrm{mg} / \mathrm{kg} \mathrm{Cu})$ has been shown to achieve similar growth performance in nursery pigs as $\mathrm{CuSO}_{4}$ supplementation at $250 \mathrm{mg} / \mathrm{kg} \mathrm{Cu}[4,5]$. Similarly, supplementation of copper methionine hydroxy analogue

Ping Ren

Ping.Ren@novusint.com

Novus International, Inc., St. Charles, MO 63304, USA chelate achieved greater average daily gain and feed efficiency in nursery or grow-finish pigs compared with pigs fed $\mathrm{CuSO}_{4}$ or tribasic copper chloride at equivalent $\mathrm{Cu}$ levels [6-9].

Copper sulfate is easily dissociated in the acidic $\mathrm{pH}$ in the stomach, allowing $\mathrm{Cu}$ to interact with phytate and resulting in the formation of $\mathrm{Cu}$-phytate complexes $[10,11]$. These complexes could impair phytase efficacy, resulting in lower $\mathrm{P}$ release from the phytate molecule $[11,12]$. An in vitro model has demonstrated that $\mathrm{Cu}$ lysine is less inhibitive to phytase compared with $\mathrm{CuSO}_{4}$ [11]. Our recent data also suggests that $\mathrm{Cu}-\mathrm{MHAC}$ may enhance phytase efficacy on bone mineralization in nursery pigs when $500 \mathrm{FTU} / \mathrm{kg}$ phytase is used, compared with $\mathrm{CuSO}_{4}$ [9]. However, there is no data on the interaction of copper source and phytase supplementation at high levels on growth performance and mineral digestibility in pigs. It is hypothesized that $\mathrm{Cu}-\mathrm{MHAC}$ could enhance the efficacy of phytase at $1500 \mathrm{FTU} / \mathrm{kg}$ on growth performance 
and mineral digestibility in nursery pigs, compared with $\mathrm{CuSO}_{4}$. Therefore, the objective of this study is to investigate the interactive effects of copper sources and phytase supplementation at $1500 \mathrm{FTU} / \mathrm{kg}$ on growth performance, nutrient digestibility, tissue mineral concentrations, and plasma parameters.

\section{Materials and Methods}

\section{Animals and Management}

The present experiment was conducted at Green Acres Animal Research and Testing Facility (Novus International, Inc., Montgomery City, MO). A total of $192 \mathrm{TR} 4 \times \mathrm{C} 22$ weaning barrows (BW $6.06 \pm 0.99 \mathrm{~kg}$; PIC, Hendersonville, TN, USA) were used in this study. Pigs were housed in plastic-coated floor pens. Each piglet was tagged for individual identification. Pigs had free access to the feed and water during the entire nursery period. A three-phase feeding program (days $0-14,15-28,29-42$ ) was used in the present study.

\section{Experimental Design and Dietary Treatments}

At weaning (day 0), piglets were weighed individually and allotted to 1 of 4 dietary treatments according to a randomized complete block design, which was blocked by initial BW. There were 12 pens per treatment and 4 pigs per pen. A basal diet for each phase was formulated to meet the energy and nutrient requirements for different stages of pigs according to the recommendation by NRC [13], with the exception that standardized total tract digestibility (STTD) $P$ was reduced by $0.12 \%$ and $\mathrm{Ca}$ level was adjusted to meet the fixed ratio of $\mathrm{Ca}$ to STTD P of 2.15. The 4 dietary treatments were arranged in a $2 \times 2$ factorial design (Table 1), with $2 \mathrm{Cu}$ sources $(125 \mathrm{ppm}$ $\mathrm{Cu}$ from copper methionine hydroxy analogue chelate $\mathrm{Cu}-$

Table 1 Description of dietary treatments in terms of copper sources and levels and phytase inclusion levels

\begin{tabular}{llll}
\hline Treatment & $\mathrm{Cu}$ sources & $\mathrm{Cu}$ levels, mg/kg & Phytase $^{\mathrm{b}}$ levels \\
\hline 1 & $\mathrm{Cu}-\mathrm{MHAC}^{\mathrm{a}}$ & 125 & 0 \\
2 & $\mathrm{CuSO}_{4}{ }^{\mathrm{a}}$ & 125 & 0 \\
3 & $\mathrm{Cu}-\mathrm{MHAC}$ & 125 & 1500 \\
4 & $\mathrm{CuSO}_{4}$ & 125 & 1500
\end{tabular}

${ }^{\mathrm{a}} \mathrm{Cu}-\mathrm{MHAC}$ represents $\mathrm{Cu}$ methionine hydroxy analogue chelate (MINTREX® $\mathrm{Cu}$ ), which is manufactured by Novus International, Inc., St. Charles, MO, USA. $\mathrm{CuSO}_{4}$ is manufactured by Old Bridge Chemicals, Inc., Old Bridge, NJ, USA

${ }^{\mathrm{b}}$ Phytase used in this study is a commercial feed-grade phytase (PHYTAVERSE®, Novus International, Inc., St. Charles, MO, USA)
MHAC, MINTREX® $\mathrm{Cu}$, Novus International, Inc., St. Charles, MO, USA) or $\mathrm{CuSO}_{4}$ (Old Bridge Chemicals, Inc., Old Bridge, NJ, USA), respectively) and 2 phytase levels ( 0 or $1500 \mathrm{FTU} / \mathrm{kg}$ phytase (PHYTAVERSE®, Novus International, Inc., St. Charles, MO, USA)). The basal diet composition for the 3 phases is presented in Table 2 .

\section{Measurements and Sample Collection}

Piglet body weights (BW) were measured at the initiation of the study (day 0 ) and at the end of each phase (days 14, 28, and 41). Feed addition to each feeder was recorded each time when the feed was added to the feeder. At the end of each phase, the remaining feed in the feeder was weighed. Average daily gain (ADG), average daily feed intake (ADFI), and gainto-feed ratio $(\mathrm{G}: \mathrm{F})$ were calculated for each phase and the entire nursery period.

Fresh fecal samples were collected via grab sampling from each pig in each pen twice a day from days 36 to 41 . The fecal samples were stored at $-20{ }^{\circ} \mathrm{C}$ immediately after collection. At the end of sample collection, fecal samples within each pen were thawed, homogenized, and immediately placed in a heated oven (NHP-PD-ECO, Win-Holt, Woodbury, NY, USA) at $65{ }^{\circ} \mathrm{C}$ for $48 \mathrm{~h}$. All dried fecal samples were ground using a rotor mill (PULVERISETTE 14, Fritsch GmbH, IdarOberstein, Germany) fitted with a 1-mm screen. Ground feces were thoroughly homogenized, and a subsample was collected for chemical analysis.

At the end of the study (day 42), one pig from each pen with the BW closest to the average BW of the pen was selected and approximately $7 \mathrm{ml}$ of blood samples was collected via jugular puncture, followed by euthanasia using captive bolt. The blood samples were centrifuged at $1500 \times \mathrm{g}$ at $4{ }^{\circ} \mathrm{C}$ for 15 min to obtain plasma samples. The third metacarpal samples were collected from selected pigs. Liver (approximately $50 \mathrm{~g}$ of the right lobe) and kidney (approximately $50 \mathrm{~g}$ of the right kidney) samples were collected in the selected pigs. The metacarpal, liver, and kidney samples were stored at $-20{ }^{\circ} \mathrm{C}$ until chemical analysis.

\section{Chemical and Biological Analyses}

Diets and feces samples were analyzed for dry matter (DM, method 934.01), Ca (method 985.01), P (method 985.01), Zn (method 985.01), and $\mathrm{Cu}$ (method 985.01) according to AOAC [14]. Phytase activity in the diets was analyzed according to ISO [15]. Gross energy was analyzed in diets and feces using an isoperibol bomb calorimeter (Model 6300, Parr Instruments, Moline, IL). Acid detergent fiber (ADF) and neutral detergent fiber (NDF) in diets and feces were analyzed using ANKOM Technology method 12 and 13, respectively (ANKOM 2000 Fiber Analyzer, ANKOM Technology, Macedon, NY). Titanium concentration in phase 3 diets and 
Table 2 Ingredient and nutrient composition of basal experimental diets (as-fed basis)

\begin{tabular}{|c|c|c|c|}
\hline Items & Phase 1 (day 0-14) & Phase 2 (day 15-28) & Phase 3 (day 29-42) \\
\hline \multicolumn{4}{|l|}{ Ingredients, $\%$} \\
\hline Corn, yellow dent & 49.10 & 54.13 & 61.45 \\
\hline Soybean meal, $47.5 \% \mathrm{CP}$ & 15.00 & 20.00 & 25.00 \\
\hline HP300 & 4.00 & 5.00 & 0.00 \\
\hline Canola meal & 4.00 & 6.00 & 10.00 \\
\hline Plasma spray-dried & 3.00 & 0.80 & 0.00 \\
\hline Whey powder & 20.00 & 10.00 & 0.00 \\
\hline Choice white grease & 2.00 & 2.00 & 1.50 \\
\hline Dicalcium phosphate $18.5 \%$ & 0.00 & 0.00 & 0.15 \\
\hline Limestone & 1.10 & 0.82 & 0.63 \\
\hline Salt & 0.30 & 0.30 & 0.30 \\
\hline Vitamin premix $^{\mathrm{a}}$ & 0.11 & 0.11 & 0.11 \\
\hline Mineral premix ${ }^{\mathrm{b}}$ & 0.29 & 0.29 & 0.29 \\
\hline Titanium dioxide & 0.00 & 0.00 & 0.40 \\
\hline $\mathrm{ZnO}, 72 \% \mathrm{Zn}$ & 0.28 & 0.00 & 0.00 \\
\hline L-lysine $\mathrm{HCl}$ & 0.49 & 0.36 & 0.17 \\
\hline $\mathrm{MHA}^{\mathrm{c}}$ & 0.19 & 0.12 & 0.00 \\
\hline L-Thr & 0.13 & 0.07 & 0.00 \\
\hline L-Trp & 0.01 & 0.00 & 0.00 \\
\hline Total & 100.00 & 100.00 & 100.00 \\
\hline \multicolumn{4}{|l|}{ Calculated nutrient composition } \\
\hline $\mathrm{ME}, \mathrm{kcal} / \mathrm{kg}$ & 3455 & 3437 & 3367 \\
\hline $\mathrm{CP}, \%$ & 20.24 & 21.24 & 20.97 \\
\hline SID $^{\mathrm{d}}$ Lys & 1.39 & 1.27 & 1.06 \\
\hline SID Thr & 0.82 & 0.75 & 0.64 \\
\hline SID Met & 0.43 & 0.39 & 0.30 \\
\hline SID Met+Cys & 0.76 & 0.70 & 0.61 \\
\hline SID Trp & 0.24 & 0.23 & 0.85 \\
\hline $\mathrm{Ca}, \%$ & 0.62 & 0.49 & 0.43 \\
\hline Total P, \% & 0.49 & 0.47 & 0.48 \\
\hline STTD $^{\mathrm{d}} \mathrm{P}, \%$ & 0.29 & 0.23 & 0.20 \\
\hline Phytate P, \% & 0.20 & 0.24 & 0.31 \\
\hline
\end{tabular}

${ }^{\text {a }}$ Supplied the following nutrients per kilogram of diets: vitamin A, 11,000 IU; vitamin D, $1760 \mathrm{IU}$; vitamin E, 83.6 IU; vitamin K, $5.5 \mathrm{mg}$; thiamine, $3.52 \mathrm{mg}$; riboflavin, $13.2 \mathrm{mg}$; niacin, $70.4 \mathrm{mg}$; pantothenic acid, $39.6 \mathrm{mg}$; pyridoxine, $7.04 \mathrm{mg}$; folic acid, $1045 \mu \mathrm{g}$; biotin, $275 \mu \mathrm{g}$; vitamin B12, $55 \mu \mathrm{g}$

${ }^{\mathrm{b}}$ The trace mineral premix supplied the following nutrients per kilogram of diets: $\mathrm{Zn}, 100 \mathrm{mg}$ as zinc sulfate; $\mathrm{Cu}$, $125 \mathrm{mg}$ as either $\mathrm{Cu}-\mathrm{MHAC}$ or $\mathrm{CuSO}_{4}$ according to Table 1; Mn, $34 \mathrm{mg}$ as manganese sulfate; $\mathrm{Fe}, 100 \mathrm{mg}$ as ferrous sulfate; $\mathrm{I}, 0.2 \mathrm{mg}$ as ethylenediamine dihydriodide; $\mathrm{Se}, 0.3 \mathrm{mg}$ as sodium selenite

${ }^{\mathrm{c}}$ MHA $®$ is a dry calcium salt of D, L-2-hydroxy-4-(methylthio)butanoic acid (84\% Met activity, MHA®, Novus International, Inc., St. Charles, MO, USA)

${ }^{\mathrm{d}}$ SID standardized ileal digestible, STTD standardized total tract digestible fecal samples was analyzed according to the procedures described by Myers et al. [16].

Plasma samples were used for malondialdehyde (MDA) analysis, which was quantified using thiobarbituric acid reactive substances assay kit 10009055 (Cayman Chemical Company, Ann Arbor, MI). Plasma inositol was measured using myo-inositol assay kit from Megazyme (Wicklow, Ireland). Growth hormone and insulin-like growth factor-1
(IGF-1) concentrations were measured using porcine growth hormone enzyme-linked immunosorbent assay (ELISA) kit from MyBioSource (San Diego, CA) and porcine IGF-1 ELISA kit, respectively.

Metacarpal, liver, and kidney samples were ashed in a muffle furnace at $600{ }^{\circ} \mathrm{C}$ overnight in porcelain crucibles. The concentrations of ash, $\mathrm{Ca}, \mathrm{P}, \mathrm{Zn}$, and $\mathrm{Cu}$ in metacarpal, liver, and kidney samples were determined using the procedure 
described by method 985.01 of AOAC [14]. Ash, Ca, and P percentages in metacarpal samples were expressed as grams of ash, $\mathrm{Ca}$, and $\mathrm{P}$ per $100 \mathrm{~g}$ of dry, fat-free metacarpal weight, respectively.

\section{Calculations}

The apparent total tract digestibility (ATTD) coefficient for $\mathrm{Ca}$ and $\mathrm{P}$ in each treatment was calculated according to equations proposed by NRC [13]. Standardized total tract digestibility of $\mathrm{Ca}$ and $\mathrm{P}$ were calculated by accounting for endogenous losses of $\mathrm{Ca}(330 \mathrm{mg} / \mathrm{kg}$ dry matter intake) [17] and P (190 mg/kg dry matter intake) [13], respectively.

\section{Statistical Analysis}

SAS® 9.4 (SAS Inst. Inc., Gary, NC) was used for all data analysis. Pen served as the experimental unit. The LSMEANS statement was used to calculate the least square means. The Tukey-Kramer adjustment was used for multiple comparisons of the least square means. Pooled SEM was calculated for each measurement. A probability of $P \leq 0.05$ was considered as significant and $0.05<P \leq 0.10$ was declared as a trend.

The GLIMMIX procedure was used to analyze all the data. Copper source, phytase level, and their interaction were considered as the fixed effects, whereas block was considered as the random effect. All the data were analyzed using default normal regression model.

\section{Results}

\section{Effect of Cu Sources and Phytase on Growth Performance}

Pigs fed diets containing $\mathrm{Cu}-\mathrm{MHAC}$ tended $(P<0.10)$ to have greater $\mathrm{G}$ :F during days $0-14$, compared with those fed diets containing $\mathrm{CuSO}_{4}$ (Table 3). Pigs fed diets containing $1500 \mathrm{FTU} / \mathrm{kg}$ phytase had greater $(P<0.05)$ ADG, ADFI, and G:F during all phases, except for G:F during days 28 41, compared with those fed diets without phytase.

There was an interaction $(P<0.05)$ between $\mathrm{Cu}$ sources and phytase in terms of BW on day 41 . When phytase was not present in the diets (P deficient), there was no difference between the two $\mathrm{Cu}$ sources in terms of BW on day 41. In contrast, when phytase was included in the diets, $\mathrm{Cu}-\mathrm{MHAC}$ tended to have greater $(P<0.10) \mathrm{BW}$ on day 41 than $\mathrm{CuSO}_{4}$. Similarly, there was an interaction $(P<0.05)$ between $\mathrm{Cu}$ sources and phytase on ADG during days $0-41$. When phytase was not present in the diets (P deficient), there was no difference between the two $\mathrm{Cu}$ sources in terms of ADG during days $0-41$. In contrast, when phytase was included in the diets, $\mathrm{Cu}-\mathrm{MHAC}$ tended to increase $(P<0.10)$ ADG during days 0-41 compared with $\mathrm{CuSO}_{4}$.

\section{Effect of Cu Sources and Phytase on Nutrient Digestibility}

The ATTD of NDF and ADF was greater $(P<0.05)$ in pigs fed diets containing $\mathrm{Cu}-\mathrm{MHAC}$ compared with pigs fed diets containing $\mathrm{CuSO}_{4}$ (Table 4). Pigs fed diets containing $\mathrm{Cu}$ MHAC had greater $(P<0.05)$ ATTD and STTD of P than those fed diets containing $\mathrm{CuSO}_{4}$. Phytase supplementation at $1500 \mathrm{FTU} / \mathrm{kg}$ increased $(P<0.01)$ ATTD of ash, $\mathrm{Ca}$, and $\mathrm{P}$, and STTD of $\mathrm{Ca}$ and $\mathrm{P}$, compared with no phytase supplementation. However, phytase supplementation at $1500 \mathrm{FTU} /$ $\mathrm{kg}$ resulted in lower $(P<0.05)$ ATTD of NDF, ADF, and gross energy, compared with no phytase supplementation.

\section{Effect of Cu Source and Phytase on Bone Mineralization}

$\mathrm{Cu}$ sources did not affect fat-free bone weight, bone ash, $\mathrm{Ca}$, $\mathrm{P}, \mathrm{Zn}$, and $\mathrm{Cu}$ concentrations from pigs on day 42 (Table 5). Phytase supplementation at $1500 \mathrm{FTU} / \mathrm{kg}$ increased $(P<0.05)$ fat-free bone weight and bone $\mathrm{P}$ concentrations compared with no phytase supplementation. Similarly, phytase supplementation at $1500 \mathrm{FTU} / \mathrm{kg}$ tended to increase $(P<0.10)$ bone ash and $\mathrm{Ca}$ concentrations compared with no phytase supplementation. However, phytase supplementation at 1500 FTU/ $\mathrm{kg}$ reduced $(P<0.01)$ bone $\mathrm{Cu}$ concentration compared with no phytase supplementation.

\section{Effect of Cu Source and Phytase on Liver and Kidney Mineral Concentrations}

There were no differences $(P>0.10)$ among the two $\mathrm{Cu}$ sources in terms of liver and kidney $\mathrm{Cu}$ and $\mathrm{Zn}$ concentrations (Table 6). Phytase supplementation at $1500 \mathrm{FTU} / \mathrm{kg}$ reduced $(P<0.01)$ liver $\mathrm{Cu}$ concentration compared with no phytase supplementation. In contrast, phytase supplementation at $1500 \mathrm{FTU} / \mathrm{kg}$ resulted in greater $(P<0.05)$ kidney $\mathrm{Cu}$ and $\mathrm{Zn}$ concentration compared with no phytase supplementation.

\section{Effect of Cu Source and Phytase on Plasma Parameters}

There were no differences $(P>0.10)$ between the two $\mathrm{Cu}$ sources in terms of plasma inositol, TBARS, growth hormone, and IGF-1 concentrations (Table 7). Phytase supplementation at $1500 \mathrm{FTU} / \mathrm{kg}$ increased $(P<0.05)$ plasma inositol and growth hormone concentrations compared with no phytase supplementation. 
Table 3 Effect of copper sources and phytase supplementation at $1500 \mathrm{FTU} / \mathrm{kg}$ on growth performance in nursery pigs ${ }^{\mathrm{C}}$

\begin{tabular}{|c|c|c|c|c|c|c|c|c|c|c|c|c|c|c|}
\hline \multirow[t]{2}{*}{ Items } & \multicolumn{2}{|l|}{$\mathrm{No}^{\mathrm{d}}$} & \multicolumn{2}{|l|}{$\mathrm{Yes}^{\mathrm{d}}$} & \multirow[t]{2}{*}{ SEM } & \multirow[t]{2}{*}{$P$ value } & \multicolumn{2}{|c|}{$\mathrm{Cu}$ sources } & \multirow[t]{2}{*}{ SEM } & \multirow[t]{2}{*}{$P$ value } & \multicolumn{2}{|c|}{ Phytase } & \multirow[t]{2}{*}{ SEM } & \multirow[t]{2}{*}{$P$ value } \\
\hline & $\mathrm{CuSO}_{4}$ & $\begin{array}{l}\mathrm{Cu}- \\
\text { MHAC }\end{array}$ & $\mathrm{CuSO}_{4}$ & $\begin{array}{l}\mathrm{Cu}- \\
\text { MHAC }\end{array}$ & & & $\mathrm{CuSO}_{4}{ }^{\mathrm{e}}$ & $\begin{array}{l}\mathrm{Cu}- \\
\mathrm{MHAC}^{\mathrm{e}}\end{array}$ & & & no & yes & & \\
\hline \multicolumn{15}{|l|}{$\mathrm{BW}, \mathrm{kg}$} \\
\hline Day 0 & 6.1 & 6.1 & 6.1 & 6.1 & 0.3 & 0.87 & 6.1 & 6.1 & 0.3 & 0.41 & 6.1 & 6.1 & 0.3 & 0.53 \\
\hline Day 14 & 9.3 & 9.4 & 10.1 & 10.3 & 0.5 & 0.71 & 9.7 & 9.8 & 0.5 & 0.31 & $9.3^{\mathrm{b}}$ & $10.2^{\mathrm{a}}$ & 0.5 & $<0.01$ \\
\hline Day 28 & 14.7 & 14.4 & 16.7 & 17.2 & 0.7 & 0.10 & 15.7 & 15.8 & 0.7 & 0.59 & $14.6^{\mathrm{b}}$ & $16.9^{\mathrm{a}}$ & 0.7 & $<0.01$ \\
\hline Day 41 & $21.9^{\mathrm{b}}$ & $21.4^{\mathrm{b}}$ & $26.0^{\text {ay }}$ & $27.6^{\mathrm{ax}}$ & 1.2 & 0.03 & 24.0 & 24.5 & 1.2 & 0.27 & $21.6^{\mathrm{b}}$ & $26.8^{\mathrm{a}}$ & 1.2 & $<0.01$ \\
\hline \multicolumn{15}{|l|}{ ADG, $g / d$} \\
\hline Days 0 to 14 & 229 & 238 & 284 & 303 & 18 & 0.69 & 257 & 270 & 16 & 0.26 & $234^{\mathrm{b}}$ & $294^{\mathrm{a}}$ & 16 & $<0.01$ \\
\hline Day s 14 to 28 & 387 & 360 & 469 & 496 & 19 & 0.12 & 428 & 428 & 15 & 0.97 & $374^{\mathrm{b}}$ & $482^{\mathrm{a}}$ & 15 & $<0.01$ \\
\hline Days 28 to 41 & $546^{\mathrm{b}}$ & $534^{\mathrm{b}}$ & $704^{\mathrm{ay}}$ & $790^{\mathrm{ax}}$ & 46 & 0.04 & 625 & 662 & 43 & 0.12 & $540^{\mathrm{b}}$ & $747^{\mathrm{a}}$ & 43 & $<0.01$ \\
\hline Days 0 to 28 & 309 & 299 & 378 & 399 & 15 & 0.09 & 343 & 349 & 13 & 0.55 & $304^{\mathrm{b}}$ & $388^{\mathrm{a}}$ & 13 & $<0.01$ \\
\hline Days 0 to 41 & $386^{\mathrm{b}}$ & $373^{\mathrm{b}}$ & $486^{\text {ay }}$ & $526^{\mathrm{ax}}$ & 23 & 0.03 & 436 & 450 & 21 & 0.26 & $380^{\mathrm{b}}$ & $506^{\mathrm{a}}$ & 21 & $<0.01$ \\
\hline \multicolumn{15}{|l|}{ ADFI, g/d } \\
\hline Days 0 to 14 & 382 & 369 & 418 & 398 & 23 & 0.83 & 400 & 383 & 21 & 0.28 & $375^{\mathrm{b}}$ & $408^{\mathrm{a}}$ & 21 & 0.04 \\
\hline Days 14 to 28 & 629 & 645 & 665 & 720 & 33 & 0.38 & 647 & 683 & 29 & 0.11 & $637^{\mathrm{b}}$ & $692^{\mathrm{a}}$ & 29 & 0.02 \\
\hline Days 28 to 41 & 805 & 778 & 996 & 1065 & 48 & 0.16 & 901 & 921 & 42 & 0.54 & $791^{\mathrm{b}}$ & $1031^{\mathrm{a}}$ & 42 & $<0.01$ \\
\hline Days 0 to 28 & 505 & 507 & 541 & 559 & 27 & 0.62 & 523 & 533 & 24 & 0.56 & $506^{\mathrm{b}}$ & $551^{\mathrm{a}}$ & 24 & 0.01 \\
\hline Days 0 to 41 & 597 & 592 & 683 & 718 & 32 & 0.32 & 640 & 655 & 28 & 0.45 & $595^{\mathrm{b}}$ & $700^{\mathrm{a}}$ & 28 & $<0.01$ \\
\hline \multicolumn{15}{|l|}{$\mathrm{G}: \mathrm{F}, \mathrm{g} / \mathrm{g}$} \\
\hline Days 0 to 14 & 0.613 & 0.650 & 0.683 & 0.763 & 0.037 & 0.48 & 0.648 & 0.707 & 0.030 & 0.06 & $0.631^{\mathrm{b}}$ & $0.723^{\mathrm{a}}$ & 0.030 & $<0.01$ \\
\hline Days 14 to 28 & 0.618 & 0.573 & 0.696 & 0.692 & 0.026 & 0.45 & 0.657 & 0.632 & 0.019 & 0.35 & $0.595^{\mathrm{b}}$ & $0.694^{\mathrm{a}}$ & 0.019 & $<0.01$ \\
\hline Days 28 to 41 & 0.675 & 0.677 & 0.696 & 0.738 & 0.032 & 0.38 & 0.685 & 0.707 & 0.028 & 0.34 & $0.67^{6}$ & 0.717 & 0.028 & 0.08 \\
\hline Days 0 to 28 & 0.613 & 0.599 & 0.690 & 0.716 & 0.019 & 0.29 & 0.652 & 0.657 & 0.014 & 0.76 & $0.606^{\mathrm{b}}$ & $0.703^{\mathrm{a}}$ & 0.014 & $<0.01$ \\
\hline Days 0 to 41 & 0.646 & 0.632 & 0.695 & 0.730 & 0.019 & 0.13 & 0.671 & 0.681 & 0.015 & 0.52 & $0.639^{\mathrm{b}}$ & $0.713^{\mathrm{a}}$ & 0.015 & $<0.01$ \\
\hline
\end{tabular}

${ }^{\mathrm{a}-\mathrm{b}}$ Within a row, means without a common superscript $\operatorname{differ}(P \leq 0.05)$. ${ }^{\mathrm{x}-\mathrm{y}}$ Within a row, means without a common superscript differ $(0.05<P \leq 0.10)$

${ }^{\mathrm{c}}$ Least square means for each treatment are calculated based on 12 replicates per treatment and 4 pigs per replicate

${ }^{\mathrm{d}}$ No and yes represent 0 and 1500 FTU/kg phytase (PHYTAVERSE®, Novus International, Inc., St. Charles, MO, USA) in the diets, respectively

${ }^{\text {e }} \mathrm{Cu}$-MHAC represents $\mathrm{Cu}$ methionine hydroxy analogue chelate (MINTREX® $\mathrm{Cu}$ ), which is manufactured by Novus International, Inc., St. Charles, $\mathrm{MO}$, USA. $\mathrm{CuSO}_{4}$ is manufactured by Old Bridge Chemicals, Inc., Old Bridge, NJ, USA

\section{Discussion}

\section{Cu Sources and Its Interaction with Phytase on Growth Performance, Nutrient Digestibility, Tissue Mineral Concentrations, and Plasma Parameters}

High levels of $\mathrm{CuSO}_{4}(150$ to $250 \mathrm{mg} / \mathrm{kg} \mathrm{Cu}$ ) are traditionally used in weaning pig diets to promote growth and improve feed efficiency $[1,7,18]$. Technology advancement has led to the development of numerous forms of organic $\mathrm{Cu}$, which have been shown to be more bioavailable than $\mathrm{CuSO}_{4}$ [3]. Studies have demonstrated that $\mathrm{Cu}$-proteinate [5] and Cu-MHAC [6, $7,9]$ achieved greater growth performance in nursery pigs than $\mathrm{CuSO}_{4}$ at the same $\mathrm{Cu}$ inclusion levels, which was further supported by the current study that $\mathrm{Cu}$-MHAC achieved greater average daily gain than $\mathrm{CuSO}_{4}$ in the presence of phytase supplementation at $1500 \mathrm{FTU} / \mathrm{kg}$. The fact that average daily gain in nursery pigs was not different between $\mathrm{Cu}-\mathrm{MHAC}$ and $\mathrm{CuSO}_{4}$ without phytase in the present study indicated that the impact of $\mathrm{P}$ deficiency might overshadow the beneficial effect of Cu-MHAC or P deficiency may impair the function and utilization of $\mathrm{Cu}$ in the body. Additionally, $\mathrm{Cu}$-citrate yielded similar growth performance as $\mathrm{CuSO}_{4}$ in nursery pigs at the same inclusion level of $\mathrm{Cu}$ [4]. It was also shown that $\mathrm{Cu}-\mathrm{MHAC}$ led to greater growth performance in nursery pigs than tribasic copper chloride at the same $\mathrm{Cu}$ inclusion levels [8]. These studies suggest that $\mathrm{Cu}$ sources play a critical role in its function and utilization in the body, thereby affecting growth performance of pigs.

Several modes of action could be responsible for the growth performance benefits by $\mathrm{Cu}-\mathrm{MHAC}$ supplementation. Firstly, $\mathrm{Cu}$ could exert antibacterial effect directly or indirectly via bile salts and therefore modulate gut microbiota [19-21]. It was reported that supplementation at $100 \mathrm{mg} / \mathrm{kg} \mathrm{Cu}$ as $\mathrm{Cu}-$ 
Table 4 Effect of copper sources and phytase supplementation at $1500 \mathrm{FTU} / \mathrm{kg}$ on total tract digestibility of nutrients in nursery pigs ${ }^{\mathrm{c}}$

\begin{tabular}{|c|c|c|c|c|c|c|c|c|c|c|c|c|c|c|}
\hline \multirow[t]{2}{*}{ Items } & \multicolumn{2}{|l|}{$\mathrm{No}^{\mathrm{d}}$} & \multicolumn{2}{|l|}{$\mathrm{Yes}^{\mathrm{d}}$} & \multirow[t]{2}{*}{ SEM } & \multirow[t]{2}{*}{$P$ value } & \multicolumn{2}{|c|}{$\mathrm{Cu}$ sources } & \multirow[t]{2}{*}{ SEM } & \multirow[t]{2}{*}{$P$ value } & \multicolumn{2}{|l|}{ Phytase } & \multirow[t]{2}{*}{ SEM } & \multirow[t]{2}{*}{$P$ value } \\
\hline & $\mathrm{CuSO}_{4}$ & $\begin{array}{l}\mathrm{Cu}- \\
\text { MHAC }\end{array}$ & $\mathrm{CuSO}_{4}$ & $\begin{array}{l}\mathrm{Cu}- \\
\text { MHAC }\end{array}$ & & & $\mathrm{CuSO}_{4}{ }^{\mathrm{e}}$ & $\begin{array}{l}\mathrm{Cu}- \\
\mathrm{MHAC}^{\mathrm{e}}\end{array}$ & & & No & Yes & & \\
\hline \multicolumn{15}{|c|}{$\operatorname{ATTD}^{\mathrm{f}}, \%$} \\
\hline Ash & 56.13 & 55.94 & 63.87 & 66.05 & 0.99 & 0.24 & 60.00 & 61.00 & 0.70 & 0.32 & $56.04^{\mathrm{b}}$ & $64.96^{\mathrm{a}}$ & 0.70 & $<0.01$ \\
\hline $\mathrm{DM}$ & 85.78 & 86.27 & 85.34 & 85.99 & 0.41 & 0.85 & 85.56 & 86.13 & 0.29 & 0.18 & 86.02 & 85.67 & 0.29 & 0.39 \\
\hline $\mathrm{EE}$ & 68.44 & 68.42 & 68.69 & 69.79 & 1.01 & 0.59 & 68.57 & 69.10 & 0.71 & 0.60 & 68.43 & 69.24 & 0.71 & 0.43 \\
\hline $\mathrm{CF}$ & 55.66 & 53.58 & 51.45 & 54.62 & 1.35 & 0.03 & 53.56 & 54.10 & 1.07 & 0.64 & 54.62 & 53.03 & 1.07 & 0.18 \\
\hline $\mathrm{CP}$ & 84.45 & 85.21 & 83.36 & 84.03 & 0.63 & 0.94 & 83.91 & 84.62 & 0.45 & 0.27 & 84.83 & 83.70 & 0.45 & 0.08 \\
\hline $\mathrm{NDF}$ & 48.60 & 51.31 & 41.91 & 47.94 & 1.35 & 0.23 & $45.26^{\mathrm{b}}$ & $49.63^{\mathrm{a}}$ & 0.96 & $<0.01$ & $49.96^{\mathrm{a}}$ & $44.93^{\mathrm{b}}$ & 0.96 & $<0.01$ \\
\hline $\mathrm{ADF}$ & 52.05 & 54.33 & 46.26 & 52.69 & 1.56 & 0.19 & $49.15^{\mathrm{b}}$ & $53.51^{\mathrm{a}}$ & 1.10 & 0.01 & $53.19^{\mathrm{a}}$ & $49.48^{\mathrm{b}}$ & 1.10 & 0.02 \\
\hline GE & 84.63 & 85.14 & 83.63 & 83.73 & 0.44 & 0.65 & 84.13 & 84.44 & 0.31 & 0.49 & $84.89^{\mathrm{a}}$ & $83.69^{\mathrm{b}}$ & 0.31 & 0.01 \\
\hline $\mathrm{Ca}$ & 65.92 & 64.55 & 79.64 & 81.12 & 1.63 & 0.39 & 72.78 & 72.84 & 1.15 & 0.97 & $65.24^{\mathrm{b}}$ & $80.39^{\mathrm{a}}$ & 1.15 & $<0.01$ \\
\hline $\mathrm{P}$ & 40.07 & 41.81 & 65.29 & 70.32 & 1.52 & 0.29 & $52.68^{\mathrm{b}}$ & $56.06^{\mathrm{a}}$ & 1.08 & 0.03 & $40.94^{\mathrm{b}}$ & $67.81^{\mathrm{a}}$ & 1.08 & $<0.01$ \\
\hline \multicolumn{15}{|c|}{$\operatorname{STTD}^{\mathrm{f}}, \%$} \\
\hline $\mathrm{Ca}$ & 71.79 & 70.42 & 85.51 & 86.99 & 1.63 & 0.39 & 78.65 & 78.70 & 1.15 & 0.97 & $71.10^{\mathrm{b}}$ & $86.25^{\mathrm{a}}$ & 1.15 & $<0.01$ \\
\hline $\mathrm{P}$ & 43.44 & 45.17 & 68.66 & 73.68 & 1.52 & 0.29 & $56.05^{\mathrm{b}}$ & $59.43^{\mathrm{a}}$ & 1.08 & 0.03 & $44.31^{\mathrm{b}}$ & $71.17^{\mathrm{a}}$ & 1.08 & $<0.01$ \\
\hline
\end{tabular}

${ }^{\mathrm{a}-\mathrm{b}}$ Within a row, means without a common superscript differ $(P \leq 0.05)$

${ }^{\mathrm{c}}$ Total tract digestibility of nutrients is determined based on fecal samples collected from days 36 to 41 post-weaning in nursery pigs. Least square means for each treatment are calculated based on 12 replicates per treatment and 1 pooled fecal sample from 4 pigs per replicate

${ }^{\mathrm{d}}$ No and yes represent 0 and $1500 \mathrm{FTU} / \mathrm{kg}$ phytase (PHYTAVERSE®, Novus International, Inc., St. Charles, MO, USA) in the diets, respectively ${ }^{\mathrm{e}} \mathrm{Cu}-\mathrm{MHAC}$ represents $\mathrm{Cu}$ methionine hydroxy analogue chelate (MINTREX® $\mathrm{Cu}$ ), which is manufactured by Novus International, Inc., St. Charles, $\mathrm{MO}, \mathrm{USA} . \mathrm{CuSO}_{4}$ is manufactured by Old Bridge Chemicals, Inc., Old Bridge, NJ, USA

${ }^{\mathrm{f}} A T T D$ apparent total tract digestibility, $D M$ dry matter, $E E$ ether extract, $C F$ crude fiber, $C P$ crude protein, $N D F$ neutral detergent fiber, $A D F$ acid detergent fiber, $G E$ gross energy, STTD standardized total tract digestibility

methionine or $\mathrm{Cu}$-proteinate increased the proportion of Lactobacillus while they reduced the proportion of Escherichia coli in the ileal digesta of broilers [22].
Supplementation of $30 \mathrm{mg} / \mathrm{kg} \mathrm{Cu}$ from Cu-MHAC in broilers decreased the proportion of Enterobacteriaceae and Firmicutes in the cecum digesta [23] compared with

Table 5 Effect of copper sources and phytase supplementation at $1500 \mathrm{FTU} / \mathrm{kg}$ on metacarpal mineralization in nursery pigs ${ }^{\mathrm{c}}$

\begin{tabular}{|c|c|c|c|c|c|c|c|c|c|c|c|c|c|c|}
\hline \multirow[t]{2}{*}{ Items } & \multicolumn{2}{|l|}{$\mathrm{No}^{\mathrm{d}}$} & \multicolumn{2}{|l|}{$\mathrm{Yes}^{\mathrm{d}}$} & \multirow[t]{2}{*}{ SEM } & \multirow{2}{*}{$\begin{array}{l}P \\
\text { value }\end{array}$} & \multicolumn{2}{|c|}{$\mathrm{Cu}$ sources } & \multirow[t]{2}{*}{ SEM } & \multirow{2}{*}{$\begin{array}{l}P \\
\text { value }\end{array}$} & \multicolumn{2}{|l|}{ Phytase } & \multirow[t]{2}{*}{ SEM } & \multirow{2}{*}{$\begin{array}{l}P \\
\text { value }\end{array}$} \\
\hline & $\mathrm{CuSO}_{4}$ & $\begin{array}{l}\mathrm{Cu}- \\
\text { MHAC }\end{array}$ & $\mathrm{CuSO}_{4}$ & $\begin{array}{l}\mathrm{Cu}- \\
\text { MHAC }\end{array}$ & & & $\mathrm{CuSO}_{4}{ }^{\mathrm{e}}$ & $\begin{array}{l}\mathrm{Cu}- \\
\mathrm{MHAC}^{\mathrm{e}}\end{array}$ & & & No & Yes & & \\
\hline $\begin{array}{c}\text { Fat-free bone } \\
\text { weight, } g\end{array}$ & 2.45 & 2.69 & 3.61 & 3.43 & 0.43 & 0.59 & 3.03 & 3.06 & 0.32 & 0.94 & $2.57^{\mathrm{b}}$ & $3.52^{\mathrm{a}}$ & 0.32 & 0.02 \\
\hline Bone ash, \% & 35.55 & 33.97 & 41.68 & 42.36 & 3.83 & 0.76 & 38.62 & 38.16 & 2.76 & 0.90 & $34.76^{\mathrm{y}}$ & $42.02^{x}$ & 2.76 & 0.06 \\
\hline $\mathrm{Ca}, \%$ & 13.04 & 12.53 & 15.11 & 15.38 & 1.41 & 0.78 & 14.07 & 13.96 & 1.03 & 0.93 & $12.79^{y}$ & $15.25^{\mathrm{x}}$ & 1.03 & 0.08 \\
\hline $\mathrm{P}, \%$ & 6.57 & 6.28 & 7.99 & 8.14 & 0.73 & 0.76 & 7.28 & 7.21 & 0.53 & 0.93 & $6.42^{\mathrm{b}}$ & $8.06^{\mathrm{a}}$ & 0.53 & 0.03 \\
\hline $\mathrm{Cu}, \mathrm{mg} / \mathrm{kg}$ & 2.87 & 2.52 & 1.85 & 1.88 & 0.25 & 0.45 & 2.36 & 2.20 & 0.17 & 0.53 & $2.69^{\mathrm{a}}$ & $1.86^{\mathrm{b}}$ & 0.17 & $<0.01$ \\
\hline $\mathrm{Zn}, \mathrm{mg} / \mathrm{kg}$ & 122.24 & 129.64 & 138.49 & 142.22 & 13.65 & 0.89 & 130.37 & 135.93 & 9.94 & 0.68 & 125.94 & 140.35 & 9.94 & 0.28 \\
\hline
\end{tabular}

${ }^{\mathrm{a}-\mathrm{b}}$ Within a row, means without a common superscript differ $(P \leq 0.05)$. ${ }^{\mathrm{x}-\mathrm{y}}$ Within a row, means without a common superscript differ $(0.05<P \leq 0.10)$

${ }^{\mathrm{c}}$ Metacarpal samples were collected from nursery pigs on day 42 post-weaning. Least square means for each treatment are calculated based on 12 replicates per treatment and 1 pig per replicate

${ }^{\mathrm{d}}$ No and yes represent 0 and 1500 FTU/kg phytase (PHYTAVERSE®, Novus International, Inc., St. Charles, MO, USA) in the diets, respectively

${ }^{\mathrm{e}} \mathrm{Cu}$-MHAC represents $\mathrm{Cu}$ methionine hydroxy analogue chelate (MINTREX® $\mathrm{Cu}$ ), which is manufactured by Novus International, Inc., St. Charles, $\mathrm{MO}, \mathrm{USA} . \mathrm{CuSO}_{4}$ is manufactured by Old Bridge Chemicals, Inc., Old Bridge, NJ, USA 
affected by the two $\mathrm{Cu}$ sources in the current study. The discrepancy among studies may be attributed to animal source and variation, sampling time, diurnal change of these hormones, and the analysis accuracy of these hormones.

Thirdly, Cu-MHAC, which is composed of one mole of $\mathrm{Cu}$ chelated with two moles of DL-2-hydroxy4-(methylthio)butanoic acid in coordinate covalent bonds, is stable in the upper gastrointestinal tract, which may minimize the formation of $\mathrm{Cu}$-phytate complex and allow more $\mathrm{Cu}$ to be absorbed by the epithelial cells in the jejunum and ileum $[2,3$, 29]. The reduction of $\mathrm{Cu}$-phytate complexes by $\mathrm{Cu}-\mathrm{MHAC}$ could also improve $\mathrm{P}$ digestibility without phytase supplementation compared with $\mathrm{CuSO}_{4}$ [29]. In contrast, approximately 40 to $50 \%$ of $\mathrm{Cu}$ in $\mathrm{CuSO}_{4}$ was formed as insoluble $\mathrm{Cu}$-phytate in the $\mathrm{pH}$ range 5.5 to 6.5 , which resulted in reduced phytase efficacy to break down the phytate molecule to release P [11]. Indeed, increasing $\mathrm{Cu}$ levels as $\mathrm{CuSO}_{4}$ in the diets containing $600 \mathrm{FTU} / \mathrm{kg}$ resulted in a linear reduction of average daily gain, feed efficiency, and apparent $\mathrm{P}$ retention rate in broilers [12], which reinforced that $\mathrm{CuSO}_{4}$ at high inclusion levels could impair phytase efficacy. However, the in vitro model demonstrated that the magnitude of inhibition on phytate hydrolysis by phytase was much less when $\mathrm{Cu}$-lysine was used as $\mathrm{Cu}$ source compared with $\mathrm{CuSO}_{4}$ [11], most likely indicating that a lower level of $\mathrm{Cu}-$ phytate complex was formed when using chelated $\mathrm{Cu}$ source. To the best of our knowledge, the current study was the first study to report increased $\mathrm{P}$ digestibility by chelated $\mathrm{Cu}$ compared with $\mathrm{CuSO}_{4}$ in pigs in the presence of phytase. It was not known why the improved P digestibility by $\mathrm{Cu}-\mathrm{MHAC}$ did not lead to increased bone $\mathrm{P}$ compared with $\mathrm{CuSO}_{4}$, which warrants further investigation. The improved $\mathrm{ADF}$ and $\mathrm{NDF}$ digestibility by $\mathrm{Cu}-$ MHAC supplementation compared with $\mathrm{CuSO}_{4}$ could also partially explain the improved growth rate in nursery pigs in this study. It has been reported that $\mathrm{Cu}$ supplementation at 10 $20 \mathrm{mg} / \mathrm{kg}$ could increase NDF digestibility in cashmere goats probably due to enhanced rumen fermentation [30]. It was probable that $\mathrm{Cu}-\mathrm{MHAC}$ supplementation could increase the number of fiber-degrading gut microbes in pigs, thereby improving fiber digestibility, compared with $\mathrm{CuSO}_{4}$.

\section{Phytase on Growth Performance, Nutrient Digestibility, Tissue Mineral Concentrations, and Plasma Parameters}

The observation that phytase increased growth performance and bone mineralization in pigs was also observed in previous experiments [31-33]. The improved growth performance and bone mineralization by phytase supplementation were mainly a result of increased P digestibility [33-35], which was consistent with the findings of the current study.

Phytate is negatively charged in aqueous solutions, especially under acidic conditions, which makes the phytate molecule bind other nutrients, including starch, protein, and minerals [36].
Additionally, phytate may bind to endogenous digestive enzymes and thereby reduce their capacity to digest nutrients [37]. As a result, increasing phytate levels in the diets may reduce pepsin activity in weanling pigs [38] and intestinal $\alpha$-amylase, sucrase, and maltase activities in chickens [39]. Phytase supplementation may result in a step-wise hydrolysis of the phytate molecule, thereby releasing phytate bound $\mathrm{P}$ and other nutrients, which may improve the digestibility of these nutrients.

Results of experiments to study phytase supplementation on the ATTD of nutrients and energy have been inconsistent. Increasing the dosage of phytase from 0 to $4000 \mathrm{FTU} / \mathrm{kg}$ did not affect the ATTD of dry matter and gross energy in growing pigs fed corn-soybean meal-based diets [40], but a linear increase in the ATTD of dry matter and gross energy was observed if the dosage of phytase was increased in corn-soybean meal diets fed to nursery pigs [41]. Increasing levels of phytase from 0 to $4000 \mathrm{FTU} / \mathrm{kg}$ did not affect the ATTD of NDF, but linearly increased the ATTD of ADF by nursery pigs fed corn-soybean meal diets [40]. However, a linear reduction in the ATTD of NDF was observed when phytase supplementation was increased from 0 to 20,000 FTU/kg in nursery pigs fed a cornsoybean meal diet [42], which was consistent with the findings of the current study. Phytase in the current study could reduce $\mathrm{Ca}$ and $\mathrm{P}$ flow to the hindgut, thereby impairing the microbial fermentation and reducing fiber digestibility [43]. The reduced fiber digestibility may partially explain the reduced energy digestibility by phytase in the present study.

It is well documented that phytase supplementation could increase $\mathrm{Zn}$ digestibility and bioavailability in pigs [9, 44-46]. However, phytase effect on $\mathrm{Cu}$ bioavailability in pigs was inconsistent. Some studies reported phytase supplementation improved $\mathrm{Cu}$ digestibility and bioavailability $[34,46]$, whereas other studies showed no response or even negative effect on $\mathrm{Cu}$ digestibility and bioavailability in pigs [45-48]. The amount of $\mathrm{Zn}$ release from the phytate complex by phytase supplementation and relative $\mathrm{Zn}$ and $\mathrm{Cu}$ concentrations in the diets might explain the various responses from different studies. Hill et al. [49] reported the antagonistic effect of excess dietary $\mathrm{Zn}$ on $\mathrm{Cu}$ availability in pigs. The antagonism between $\mathrm{Zn}$ and $\mathrm{Cu}$ is primarily mediated through the absorption process, where $\mathrm{Zn}$ induces high concentrations of metallothionein in the intestinal mucosa and the binding affinity of metallothionein for $\mathrm{Cu}$ is greater than $\mathrm{Zn}$ $[50,51]$. The $\mathrm{Cu}$ bound to metallothionein is not absorbed and sloughed with mucosal cells, therefore reducing $\mathrm{Cu}$ bioavailability [52]. To our best knowledge, it is the first study to report the increased kidney $\mathrm{Cu}$ concentrations caused by phytase supplementation, along with the reduced bone and liver $\mathrm{Cu}$ concentrations. It seems that the improved $\mathrm{Zn}$ bioavailability caused by phytase supplementation at $1500 \mathrm{FTU} / \mathrm{kg}$ not only impacts $\mathrm{Cu}$ absorption in the intestinal level but also shifts $\mathrm{Cu}$ metabolism and distribution among various tissues, including bone, liver, and kidney. Further studies are warranted to explore this intriguing question. 
Numerous studies have reported that phytase supplementation above $1000 \mathrm{FTU} / \mathrm{kg}$ could lead to increased plasma inositol concentration in pigs and broilers [53-55]. It has been suggested that inositol could stimulate insulin signaling pathway and protein synthesis [56], which may explain the improved growth performance of phytase supplementation above $1000 \mathrm{FTU} / \mathrm{kg}$ in pigs and broilers [54, 57]. Plasma growth hormone concentration was reduced under phosphorus deficiency in broilers [58, 59]. It could be speculated that increased $\mathrm{P}$ bioavailability by phytase supplementation at $1500 \mathrm{FTU} / \mathrm{kg}$ in the current study may contribute to enhanced pituitary activity and thereby higher growth hormone secretion. The increased plasma inositol and growth hormone may partially explain the improved growth performance by phytase in the present study.

In conclusion, $\mathrm{Cu}-\mathrm{MHAC}$ led to greater growth rate in nursery pigs than $\mathrm{CuSO}_{4}$ in the presence of phytase supplementation at $1500 \mathrm{FTU} / \mathrm{kg}$. Cu-MHAC enhanced fiber and $\mathrm{P}$ digestibility regardless of phytase in comparison with $\mathrm{CuSO}_{4}$. Phytase addition to P-deficient diets was effective in improving growth performance, $\mathrm{Ca}$ and $\mathrm{P}$ digestibility, and plasma inositol and growth hormone concentrations.

Funding The study was funded by Novus International, Inc.

Data Availability The datasets generated during and/or analyzed during the current study are available from the corresponding author on reasonable request.

\section{Compliance with Ethical Standards}

Conflict of Interest All authors are employees of Novus International, Inc.

Ethics Approval The animal protocols used in the current study were approved by Novus International, Inc. Animal Ethics Committee.

Open Access This article is licensed under a Creative Commons Attribution 4.0 International License, which permits use, sharing, adaptation, distribution and reproduction in any medium or format, as long as you give appropriate credit to the original author(s) and the source, provide a link to the Creative Commons licence, and indicate if changes were made. The images or other third party material in this article are included in the article's Creative Commons licence, unless indicated otherwise in a credit line to the material. If material is not included in the article's Creative Commons licence and your intended use is not permitted by statutory regulation or exceeds the permitted use, you will need to obtain permission directly from the copyright holder. To view a copy of this licence, visit http://creativecommons.org/licenses/by/4.0/.

\section{References}

1. Cromwell GL, Stahly TS, Monegue HJ (1989) Effects of source and level of copper on performance and liver copper stores in weanling pigs. J Anim Sci 67:2996-3002
2. Yi GF, Atwell CA, Hume JA, Dibner JJ, Knight CD, Richards JD (2007) Determining the methionine activity of Mintrex organic trace minerals in broiler chicks by using radiolabel tracing or growth assay. Poult Sci 86:877-887. https://doi.org/10.1093/ps/ 86.5.877

3. Richards JD, Zhao JM, Harrell RJ, Atwell CA, Dibner JJ (2010) Trace mineral nutrition in poultry and swine. Asian-Australasian J Anim Sci 23:1527-1534. https://doi.org/10.5713/ajas.2010.r.07

4. Armstrong TA, Cook DR, Ward MM, Williams CM, Spears JW (2004) Effect of dietary copper source (cupric citrate and cupric sulfate) and concentration on growth performance and fecal copper excretion in weanling pigs. J Anim Sci 82:1234-1240. https://doi. org $/ 10.2527 / 2004.8241234 x$

5. Veum TL, Carlson MS, Wu CW, Bollinger DW, Ellersieck MR (2004) Copper proteinate in weanling pig diets for enhancing growth performance and reducing fecal copper excretion compared with copper sulfate. J Anim Sci 82:1062-1070. https://doi.org/10. 2527/2004.8241062x

6. Zhao J, Allee G, Gerlemann G, Ma L, Gracia MI, Parker D, Vazquez-Anon M, Harrell RJ (2014) Effects of a chelated copper as growth promoter on performance and carcass traits in pigs. Asian-Australasian J Anim Sci 27:965-973. https://doi.org/10. 5713/ajas.2013.13416

7. Ma YL, Zanton GI, Zhao J, Wedekind K, Escobar J, VazqueZAñón M (2015) Multitrial analysis of the effects of copper level and source on performance in nursery pigs. J Anim Sci 93:606614. https://doi.org/10.2527/jas.2014-7796

8. Carpenter CB, Woodworth JC, DeRouchey JM, Tokach MD, Goodband RD, Dritz SS, Wu FZ, Usry JL (2019) Effects of increasing copper from tri-basic copper chloride or a copper-methionine chelate on growth performance of nursery pigs. Transl Anim Sci 3: 369-376. https://doi.org/10.1093/tas/txy091

9. Ren P, Chen J, Wedekind K, Hancock D, Vazquez-Anon M (2020) Interactive effects of zinc, copper sources and phytase on growth performance, mineral digestibility, bone mineral concentrations, oxidative stress, and gut morphology in nursery pigs. Transl Anim Sci 4:1-16. https://doi.org/10.1093/tas/txaa083

10. Dintzis FR, Laszlo JA, Nelsen TC, Baker FL, Calvert CC (1995) Free and total ion concentrations in pig digesta. J Anim Sci 73: 1138-1146. https://doi.org/10.2527/1995.7341138x

11. Pang YF, Applegate TJ (2006) Effects of copper source and concentration on in vitro phytate phosphorus hydrolysis by phytase. $\mathrm{J}$ Agric Food Chem 54:1792-1796. https://doi.org/10.1021/ jf052053b

12. Banks KM, Thompson KL, Jaynes P, Applegate TJ (2004) The effects of copper on the efficacy of phytase, growth, and phosphorus retention in broiler chicks. Poult Sci 83:1335-1341. https://doi. org $/ 10.1093 / \mathrm{ps} / 83.8 .1335$

13. NRC (2012) Nutrition requirements of swine, 11th edn. National. Academy Press, Washington, DC

14. AOAC (2006) Official methods of analysis, 18th edn. Association of Official Analytical Chemists, Gaitherburg

15. ISO (2009) Standard 30024. Animal feeding stuffs-Determination of phytase activity. International Organization for Standardization, Geneva, Switzerland

16. Myers WD, Ludden PA, Nayigihugu V, Hess BW (2004) Technical note: a procedure for the preparation and quantitative analysis of samples for titanium dioxide. J Anim Sci 82:179-183. https://doi.org/10.2527/2004.821179x

17. Merriman LA, Stein HH (2016) Particle size of calcium carbonate does not affect apparent and standardized total tract digestibility of calcium, retention of calcium, or growth performance of growing pigs. J Anim Sci 94:3844-3850. https://doi.org/10.2527/jas.20150252

18. Jongbloed AW, Bikker P, Thissen JTNM (2011) Dose-response relationships between dietary copper level and growth performance 
in piglets and growing-finishing pigs and effect of withdrawal of a high copper level on subsequent growth performance. Report 483, Lelystad (The Netherlands): Wageningen UR Livestock Research. http://www.livestockresearch.wur.nl

19. Shurson GC, Ku PK, Waxler GL, Yokoyama MT, Miller ER (1990) Physiological relationships between microbiological status and dietary copper levels in the pig. J Anim Sci 68:1061-1071. https://doi.org/10.2527/1990.6841061x

20. Zhou W, Kornegay ET, Lindemann MD, Swinkels JW, Welten MK, Wong EA (1994) Stimulation of growth by intravenous injection of copper in weanling pigs. J Anim Sci 72:2395-2403. https:// doi.org/10.2527/1994.7292395x

21. Arnold MA (2011) Interaction of copper source, bile composition on microbial growth, and $\mathrm{Cu}$ protein homeostasis. Master thesis. Colorado State University, Fort Collins, CO

22. Kim GB, Seo YM, Shin KS, Rhee AR, Han J, Paik IK (2011) Effects of supplemental copper-methionine chelate and coppersoy proteinate on the performance, blood parameters, liver mineral content, and intestinal microflora of broiler chickens. J Appl Poult Res 20:21-32. https://doi.org/10.3382/japr.2010-00177

23. Chen J, Wedekind KJ, Wineman TD, Vazquez-Añón M, Escobar J (2016) Effect of chelated copper on gut health in broilers. Poult Sci 95(E-Suppl. 1):105

24. Zhou W, Kornegay ET, van Laar H, Swinkels JW, Wong EA, Lindemann MD (1994) The role of feed consumption and feed efficiency in copper-stimulated growth. J Anim Sci 72:23852394. https://doi.org/10.2527/1994.7292385x

25. Yang WY, Wang JG, Liu L, Zhu XY, Wang XX, Liu ZX, Wang Z, Yang LY, Liu GW (2011) Effect of high dietary copper on somatostatin and growth hormone-releasing hormone levels in the hypothalami of growing pigs. Biol Trace Elem Res 143:893-900. https://doi.org/10.1007/s12011-010-8904-x

26. Yang WY, Wang JG, Zhu XY, Gao YH, Liu ZX, Zhang L, Chen H, Shi XX, Yang LY, Liu GW (2012) High lever dietary copper promote ghrelin gene expression in the fundic gland of growing pigs. Biol Trace Elem Res 150:154-157. https://doi.org/10.1007/ s12011-012-9477-7

27. Wang JG, Zhu XY, Guo YZ, Wang Z, Zhao BY, Yin YH, Liu GW (2016) Influence of dietary copper on serum growth-related hormone levels and growth performance of weanling pigs. Biol Trace Elem Res 172:134-139. https://doi.org/10.1007/s12011015-0574-2

28. Gonzalez-Esquerra R, Araujo RB, Haese D, Kill JL, Cunha AF, Monzani PS, Lima CG (2019) Effect of dietary copper sources on performance, gastric ghrelin-RNA expression, and growth hormone concentrations in serum in piglets. J Anim Sci 97:4242-4247. https://doi.org/10.1093/jas/skz282

29. Liu Y, Ma YL, Zhao JM, Vazquez-Anon M, Stein HH (2014) Digestibility and retention of zinc, copper, manganese, iron, calcium, and phosphorus in pigs fed diets containing inorganic or organic minerals. J Anim Sci 92:3407-3415. https://doi.org/10.2527/ jas2013-7080

30. Zhang W, Wang R, Zhu X, Kleemann DO, Yue C, Jia Z (2007) Effects of dietary copper on ruminal fermentation, nutrient digestibility and fiber characteristics in cashmere goats. Asian-Aust $\mathrm{J}$ Anim Sci 20:1843-1848. https://doi.org/10.5713/ajas.2007.1843

31. Kuhn I, Manner K (2012) Performance and apparent total tract phosphorus and calcium digestibility in grower-finisher pigs fed diets with and without phytase. J Anim Sci 90:143-145. https:// doi.org/10.2527/jas.53829

32. Santos TT, Walk CL, Wilcock P, Cordero G, Chewning J (2014) Performance and bone characteristics of growing pigs fed diets marginally deficient in available phosphorus and a novel microbial phytase. Can J Anim Sci 94:493-497. https://doi.org/10.4141/ cjas2013-190
33. Ren P, Blavi L, Gonzalez-Vega C, Liu YH, Hancock D, VazquezAnon M, Almeida FN, Stein HH (2020) Effects of a novel E. coli phytase expressed in Pseudomonas fluorescens on growth, bone mineralization and nutrient digestibility in pigs fed corn-soybean meal diets. Transl Anim Sci. https://doi.org/10.1093/tas/txaa201

34. Kies AK, Kemme PA, Sebek LBJ, van Diepen JTM, Jongbloed AW (2006) Effect of graded doses and a high dose of microbial phytase on the digestibility of various minerals in weaner pigs. J Anim Sci 84:1169-1175. https://doi.org/10.2527/2006.8451169x

35. Adedokun SA, Owusu-Asiedu A, Ragland D, Plumstead P, Adeola O (2015) The efficacy of a new 6-phytase obtained from Buttiauxella spp. expressed in Trichoderma reesei on digestibility of amino acids, energy, and nutrients in pigs fed a diet based on corn, soybean meal, wheat middlings, and corn distillers' dried grains with solubles. J Anim Sci 93:168-175. https://doi.org/10. 2527/jas.2014-7912

36. Noureddini H, Dang J (2009) Degradation of phytates in distillers grains and corn gluten feed by Aspergillus niger phytase. Appl Biochem Biotechnol 159:11-23. https://doi.org/10.1007/s12010008-8365-2

37. Selle PH, Ravindran V, Bryden WL, Scott T (2006) Influence of dietary phytate and exogenous phytase on amino acid digestibility in poultry: a review. Jpn Poult Sci 43:89-103. https://doi.org/10. 2141/jpsa.43.89

38. Woyengo TA, Adeola O, Udenigwe CC, Nyachoti CM (2010) Gastro-intestinal digesta $\mathrm{pH}$, pepsin activity and soluble mineral concentration responses to dietary phytic acid and phytase in piglets. Livest Sci 134:91-93. https://doi.org/10.1016/j.livsci.2010.06. 107

39. Liu N, Ru YJ, Li FD, Cowieson AJ (2008) Effect of diet containing phytate and phytase on the activity and messenger ribonucleic acid expression of carbohydrase and transporter in chickens. J Anim Sci 86:3432-3439. https://doi.org/10.2527/jas.2008-1234

40. She Y, Sparks JC, Stein HH (2018) Effects of increasing concentrations of an Escherichia coli phytase on the apparent ileal digestibility of amino acids and the apparent total tract digestibility of energy and nutrients in corn-soybean meal diets fed to growing pigs. J Anim Sci 96:2804-2816. https://doi.org/10.1093/jas/sky152

41. Arredondo MA, Casas GA, Stein HH (2019) Increasing levels of microbial phytase increases the digestibility of energy and minerals in diets fed to pigs. Anim Feed Sci Technol 248:27-36. https://doi. org/10.1016/j.anifeedsci.2019.01.001

42. Zeng ZK, Li QY, Zhao PF, Xu X, Tian QY, Wang HL, Pan L, Yu S, Piao XS (2016) A new phytase continuously hydrolyzes phytate and improves amino acid digestibility and mineral balance in growing pigs fed phosphorous-deficient diet. J Anim Sci 94:629-638. https://doi.org/10.2527/jas.2015-9143

43. Metzler BU, Mosenthin R, Baumgärtel T, Rodehutscord M (2008) The effect of dietary phosphorus and calcium level, phytase supplementation, and ileal infusion of pectin on the chemical composition and carbohydrase activity of fecal bacteria and the level of microbial metabolites in the gastrointestinal tract of pigs. J Anim Sci 86: 1544-1555. https://doi.org/10.2527/jas.2007-0267

44. Lei X, Ku PK, Miller ER, Ullrey DE, Yokoyama MT (1993) Supplement microbial phytase improves bioavailability of dietary zinc to weanling pigs. J Nutr 123:1117-1123. https://doi.org/10. 1093/jn/123.6.1117

45. Bikker P, Jongbloed AW, Thissen JTNM (2012) Meta-analysis of effects of microbial phytase on digestibility and bioavailability of copper and zinc in growing pigs. J Anim Sci 90:134-136. https:// doi.org/10.2527/jas.53798

46. Bikker P, van Diepen JTM, Binnendijk GP, Jongbloed AW (2012) Phytase inclusion in pig diets improves zinc status but its effect on copper availability is inconsistent. J Anim Sci 90:197-199. https:// doi.org/10.2527/jas.53907 
47. Adeola O (1995) Digestive utilization of minerals by weanling pigs fed copper- and phytase-supplemented diets. Can J Anim Sci 75: 603-610. https://doi.org/10.4141/cjas95-089

48. Zacharias B, Ott H, Drochner W (2003) The influence of dietary microbial phytase and copper on copper status in growing pigs. Anim Feed Sci Technol 106:139-148. https://doi.org/10.1016/ S0377-8401(03)00007-5

49. Hill GM, Ku PK, Miller ER, Ullrey DE, Losty TA, O’Dell BL (1983) A copper deficiency in neonatal pigs induced by a high zinc maternal diet. J Nutr 113:867-872. https://doi.org/10.1093/jn/113. 4.867

50. Cousins RJ (1985) Absorption, transport and hepatic metabolism of copper and zinc: special reference to metallothionein and ceruloplasmin. Physiol Rev 65:238-309. https://doi.org/10.1152/physrev. 1985.65.2.238

51. Oestreicher P, Cousins RJ (1985) Copper and zinc absorption in the rat: mechanism of mutual antagonism. J Nutr 115:159-166. https:// doi.org/10.1093/jn/115.2.159

52. Fischer PWF, Giroux A, L'Abbe MR (1983) Effects of zinc on mucosal copper binding and on the kinetics of copper absorption. J Nutr 113:462-469. https://doi.org/10.1093/jn/113.2.462

53. Cowieson AJ, Aureli R, Guggenbuhl P (2015) Possible involvement of myo-inositol in the physiological response of broilers to high doses of microbial phytase. Anim Prod Sci 55:710-719. https://doi.org/10.1071/AN14044

54. Moran K, Wilcock P, Elsbernd A, Zier-Rush C, Boyd RD, van Heugten E (2019) Effects of super-dosing phytase and inositol on growth performance and blood metabolites of weaned pigs housed under commercial conditions. J Anim Sci 97:3007-3015. https:// doi.org/10.1093/jas/skz156

55. Sommerfeld V, Künzel S, Schollenberger M, Kühn I, Rodehutscord M (2018) Influence of phytase or myo-inositol supplements on performance and phytate degradation products in the crop, ileum, and blood of broiler chickens. Poult Sci 97:920-929. https://doi. org/10.3382/ps/pex390

56. Croze ML, Soulage CO (2013) Potential role and therapeutic interests of myo-inositol in metabolic diseases. Biochimie 95:18111827. https://doi.org/10.1016/j.biochi.2013.05.011

57. Walk CL, Bedford MR, Santos TS, Paiva D, Bradley JR, Wladecki H, Honaker C, McElroy AP (2013) Extra-phosphoric effects of superdoses of a novel microbial phytase. Poult Sci 92:719-725. https://doi.org/10.3382/ps.2012-02727

58. Carew LB, Gestone TA, Alster FA (1985) Effect of a phosphorus deficiency on thyroid function and growth hormone in the white leghorn male. Poult Sci 64:2010-2012. https://doi.org/10.3382/ps. 0642010

59. Parmer TG, Carew LB, Alster FA (1987) Thyroid function, growth hormone, and organ growth in broilers deficient in phosphorus. Poult Sci 66:1995-2004. https://doi.org/10.3382/ps.0661995

Publisher's Note Springer Nature remains neutral with regard to jurisdictional claims in published maps and institutional affiliations. 